\title{
THE STEPS \\ (Dissertations the fruit growing troll)
}

\author{
Dezső Surányi \\ Fruit Research Institute, Cegléd. p. 310.
}

The Steps (Dissertations the fruit growing troll) on front-page of volume are visible ruins and stairway of the famous Machu Picchu. Five selfdetermined head stands the volume, essentially the author yet career one one station, which the plant sexuality, the fruit cropping and sure environmental and plant health problems searching is comprising reached results engaged on 310 page, with 130 tables and 79 figures. The volume is brandnew notification shape in Hungarian and international scientific literature.

\section{Chapter I}

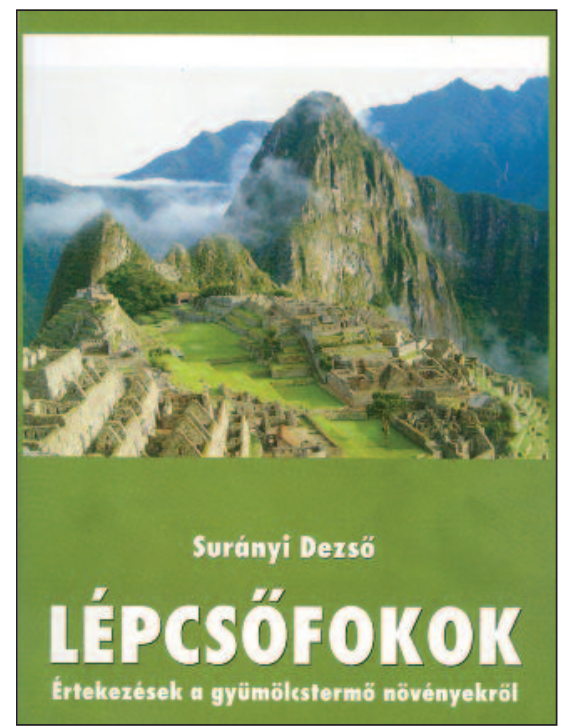

cv. Magyar kajszi on rootstock of wild apricot, myrobalane, plum and amygdalopersica scouted yearly shoot growth, yield of trees, as well as the fruit size data, and normal the trees token or total abandon standard. The raise and local plums there had been best rootstocks for the cv. Magyar kajszi apricot trees. Over and above that surveyed the author a very sensible type of dieback, as cv. Ceglédi bíborkajszi 4-5 age-old scions scanned partly myrobalane subjective inoculated with Besztercei szilva plum's stem trees by overgrafting, partly the Ceglédi bíborkajszi were used stem also - these given the plant matter.

There were infecting artful contagion

Physiological effects of growth retardants and their possibilities in modern fruit growing (1967)

The Chapter I head deals the as in 1960's years unearthed and multiple tried growth retardants its effects, usually the author gave the test plants got results reviewing processing. There were investigated the fruit plants won first results on the basis wild pear and wild apricot seedlings by affectivity of CCC in the greenhouse. Promissory note results were born hey-day in fruit regulating, improvement of fruit quality and resistance, but the author has reasonable ground for believing that necessary is wariness with retardant chemicals.

Further on, by author through plotted enchiridion already resolutely invite his attention the possible risks, mainly human and environmental spacious. Unfortunately since then, neither even adulterants yield and the fruit regulating nor utilize the results around in the world the expect standard.

\section{Chapter II}

\section{Effects of different rootstocks and stem making on} apricot bearing trees and scions (1976)

In Hungary also important question is the dieback of apricot trees in early and bearing period. The problem yet today nor undid. The Chapter II can be readable behaviour of fungi Cytospora cincta and Pseudomonas syringae bacterium and the two solidly led stems or twigs of trees into phloem and cambium. The results verified xylotomical and transpiration trials, that the Besztercei szilva plum, than stem-making every mechanical, every physiological underway inhibited the apoplexy effecting pathogen structures unwholesome its effects. Unfortunately, the two times grafted trees than $30 \%$ increases the setup outlays, thus the growers tight confines between take this the scion training method.

\section{Chapter III}

\section{Morphogenetical characteristics and their relationships in androecium and gynoecium of some genus of subfamily Prunoideae (1978)}

During 1968-1971 and 1969-1972 were investigated 5 almond, 10 apricot, 13 peach, 16 plum, 3 myrobalane as cherry plum, 9 sweet cherry, 9 sour cherry and mahaleb species, cultivars and clone type of investigated matter. The author modeled new method for sex organs in flowers, which also published in HortScience (1976. 11, 406-407). It had been the mentioned species out of 19 self-fertile, 19 partly self-fertile and 29 type but self-sterile. Very specific ratio of pistil length, stamen number and stamen number/pistil length 
ratio (SN/PL) are and annual fluctuation miniature. Mainly typical worth is the relative stamen number.

There were compared to self-sterile species, everything genre in the event of, smaller the relative stamen of selffertile and partly self-fertile stone fruits compared to. The author defined the unmanly, characteristics (as idea) of male character and the ideal self-fertile species. The 67 stone fruits out of 47 type in the event of significantly sampled the pistil length and the stamen number sex correlation, the legality species benchmark also valid.

All data of each flowers on self-fertile and partly self-fertile varieties $(n=4.560)$, as well as self-sterile cultivars $(n=3.480)$ with pistil length and stamen number, the regression relationship differences the relative stamen number according to odds it explained. The author can be demonstrating the differences incomplete (pistil without), polycarpic and staminodia flowers structurally odds to the normal flowers too.

The main conclusions of chapter, that results fitter can be, evaluate cultivars, hybrids and different phytotechnical treatments.

\section{Chapter IV}

\section{Flower structure of historical and cultivated plum varieties, the relationship of morphological traits and self-fertility (1985)}

Than 10 thousand cases of Prunus flower particular survey statutory you can say ratios take up the between flower compartments. The teloma theory on the basis innuendo the pistil than dominant positioned teloma part the ruffed situation pounces numerical occurrence between numerical connections certifiable.

The numerical morphology and taxonomy on this results yet rather the installments considering the author upon studied the Chapter IV - the raise and collection species troll the floral and fertilization biologic question exculpation.

It had been 80 plum cultivars out of 26 self-fertile, 11 partly self-fertile, 11 practically self-sterile and fully selfsterile types during 1975-1980. The fruit skin colour according to partion the next one: 32 blue, 26 violet, 5 red, 12 yellow and 5 it's green fruit stone fruit type, whilst the stamen according to allotment according to 7 type 20stamen, 24 type 25 -stamen, 38 type 30 -stamen and 11 type 35 -stamen were. The study basically reported than 15 thousand flower particular dimensional and numerical surveying (according to 14-trait of cultivars).

The author so found, that between the sexual organs correlation mathematical different on the varieties of things in connection of self-fertile disposition. The changes of pistil length on self-fertile and partly self-fertile cultivars and flowers much sensible respond the androecium, than that self-sterile cases and cultivars in the event of this the stamens well reflect.

There is decreasing his chance of self-fertility between stage of under $1,30 \mathrm{pc} / \mathrm{mm}$ (partly self-fertile cvs) and over
$1,70 \mathrm{pc} / \mathrm{mm}$ (self-sterile cvs) of relative stamen number, that way or too female-type, or far-fetched male-type will be the plum's flower. Other sexual organ, but because of that lessened to the situation run into. (M. Faust inherited this sexual model in her book, 1989, p. 185.) The presented fundamental morphogenetical peculiar on the basis the relative stamen, the diameter of stigma and the apistile, as well as polycarp flowers prevalence the uppermost characteristics, these worth dynamically version and argumentative warp the fertility view.

Summarily, it can be establish, that size relations of sexual organs, i.e. scale not optional in plum flowers nor, but competitive in contact sty with each other. The value of singular flower compartments not only with each other linked version, but the external factors also affect onto them. These evident data too statutory changes suitably vary the morphologically (structurally) and fertility (functionary) ratios.

In the paradigm of flower structure the new conception and results largely facilitate validate latter-day picturesque comparison of cultivars, improvable study (primarily selection) and valuation of agrotechnical results, and speeds also.

\section{Chapter V}

\section{Importance of cultivars, rootstocks and environment in the extension of plum growing (1991)}

The plum is second uppermost fruit species the apple behind. But how long? It is role decrease show up role of national economic and plum growing, but the nutritional significance of plum not.

The plum growing at us it had passed heterogeneous decade unchanged arrives to crisis, than most managing fruit growing in my jaw. The anachronistic (bad) structure of cultivars and rootstock's use, the low standards growing technological plans, the absolutely the sort of things existing agrobiological (irregular fruit cropping, self-sterility of flowers, frost sensitivity small making fruit, incompatibility between rootstock and scion, over and above that plant constitutional virus, monilia and polistygma upon susceptibility) our problems and sure unfavorable economics and social (table value, consumption) states exceptive headaches his sources.

Besztercei plum dominant managing role departed more cause also. The variety's offer accruements unquestioned: joyous and dangerous, while of big fruit and untimely cultivars from their dissemination resulting preferences at the market redeemers not it's enjoying it (dearness) and this cultivars greater the growers risk also. The traditional cultivars as Besztercei szilva, Italian blue still searched in canned and mirelite industry. The distilling industry also invariably important mass claiming the plum fruits, for the most the savory, cheap plum fruit ranch. The Hungarian culinary requirements as well rather the erstwhile traditional plum turns to. 
After1977 perceptible it had been the cultivar's change, the dominancy of cv. Stanley unique stoned, then the Èàanska lepotica became it managing, while these together new headaches also check in self-sterility, frost sensibility, rootstock incompatibility, weak drought resistance etc.). More question untouched the floral morphological and fruit regulating cases with problems, which studiously the type and the environmental character.

The characteristic of cultivars (genetic quality) means partly a determinate physiomorphological character (vegetative and reproductive achievement), partly sure environmental conditions (clime, soil, rootstock, diseases, growing technical factors) truly adaptive and resistant capacity. There were analyzing on the basis with many-sided trials the cultivars, rootstocks, age of trees and phytotechnical way. Absolutely Chapter V rootstock's effect, moreover clone selection of singular cultivars also.

The volume set apart each chapter the literary springs too. The book of Steps retrospective labour of D. Surányi is and a sum of her activity yet and the continuation plights. There had been lectors of chapters the Hungarian prominent professional scientists. 